\title{
CFSP Reform and Transatlantic Relations
}

\author{
by Ettore Greco *
}

\section{Introduction}

The diplomatic crisis over intervention in Iraq exposed once again the structural deficiencies of the European Union's foreign policy. In the 1990s the Union's member states had already proven themselves unable to cope effectively with major international crises. But their inability to take unified positions and actions during the Iraq crisis was also compounded by unprecedented tensions between a few of them, notably France and Germany, and the United States, something which cast a dark shadow over the future of the transatlantic security partnership.

The Union's disarray over the Iraq crisis took place at the very moment when it was engaged in a major effort to streamline and enhance its institutions and instruments for external action. This was indeed one of the main objectives of the European Convention which, after seventeen months of work, in July approved a new draft constitutional treaty for the EU. There was a widespread fear that the deep contrasts that emerged between various EU member states over the Iraqi crisis and the related transatlantic rift could have a damaging effect on the Convention or even derail it. For this reason the President of the Convention, Valery Giscard d'Estaing, wisely postponed the discussion on the articles of the draft constitutional treaty concerning the Union's Common Foreign and Security Policy (CFSP) until after the conclusion of the military campaign in Iraq. In fact, the Convention eventually approved a set of reform measures which, if endorsed by the EU's intergovernmental conference, which is due to start next October, would substantially change the Union's modus operandi in the CFSP realm.

Indeed, in the last few years, and especially after September 11, the number of European citizens who support the strengthening and expansion of the EU's foreign and security policy has constantly grown. According to the most recent opinion polls, an overwhelming majority of Europeans are today in favor of a stronger CFSP. The leaders of the member states, including those that are less integrationist, have also shown a growing awareness of the need to equip the Union with more effective instruments for external projection. The Convention's proposals to reform the CFSP reflect this change in attitude. However, whether they are strong enough to ensure the increased effectiveness and consistency of the Union as an international actor in general and in its relations with the U.S. in particular is a matter for discussion.

This paper provides a brief analysis of the new provisions regarding the CFSP contained in the draft constitutional treaty approved by the

\footnotetext{
* Ettore Greco is Deputy Director of the Istituto Affari Internazionali, Rome.
} 
Convention, with a focus on their most innovative aspects. It also tries to assess the extent to which these provisions can actually contribute to reinforcing the EU's international role and its capacity to promote a more effective and balanced transatlantic partnership.

\section{Loyalty and Mutual Solidarity}

The draft treaty obligates the member states: (a) to comply fully with the Union's CFSP positions and actions, and; (b) to consult one another on any CFSP issue of general interest. This includes the commitment to provide prior information on any national foreign policy position or action. The wording of the text reflects the effort to reaffirm the bonds of loyalty linking the member states in the CFSP area. Indeed, after the failure of the EU to reach a common position on Iraq, the debate has concentrated on how to ensure that, in future crisis situations, rapid and effective consultations take place within the EU, possibly leading to common positions and actions. Hence the emphasis placed in the text on the obligations that the member states undertake in the field of CFSP. In fact, equivalent (if not identical) loyalty clauses related to CFSP can also be found in the EU treaty currently in force. However, CFSP is not a policy area that is readily amenable to enforcement. The European Court of Justice, the EU's body that holds the mandate to ensure respect for the Union's law, can hardly be given the power of sanction for cases of non-compliance with CFSP obligations.

On the other hand, the draft constitutional treaty envisages the establishment of new institutional bodies that could prove instrumental in ensuring the member states' compliance with their commitments to mutual consultation and solidarity in the CFSP field. This applies, in particular, to the proposed Minister of Foreign Affairs (MFA), who would take over all the tasks currently divided between the commissioner for external relations and the high representatives for CFSP. The MFA would have primary responsibility for, inter alia, ensuring the implementation of common CFSP decisions and coordination and consistency between various foreign policy initiatives. With his/her large power of initiative, the MFA could also push the member states to undertake early reciprocal consultation and early action at times of crisis. In this regard, a key role could also be played by the proposed new full-time President of the European Council, an elected official who would replace the current six-month rotating presidency. He/she would have the power to convene an extraordinary meeting of the European Council if international developments so require. In the future, the actions of these new institutional bodies could hopefully allow the Union to avoid a repetition of the Iraqi failure.

The draft constitutional treaty also reinforces the bonds of solidarity between the member states through a new clause directly relating to the new security concerns that emerged after the events of 11 September 2001. It pro- 
poses that the member states "shall act jointly in a spirit of solidarity if a Member State is the victim of terrorist attack or natural or man-made disaster." The text explicitly mentions eventual common military action to "prevent the terrorist threat in the territory of the member states." This new commitment by the EU countries to use military means, when needed, to cope with terrorist threats - even in a preventive mood - can provide the basis also for a greater convergence with the anti-terrorism efforts of the United States.

\section{The Scope of the CFSP}

The draft constitutional treaty reaffirms that the CFSP "shall cover all areas of foreign policy and all questions relating to the Union's security.” In practice, however, owing to a lack of political will or fundamental divergences of interest between the member states, the Union's foreign policy continues to have a fairly limited scope - that is, it only covers a selected number of issues and geographical areas. In particular, while the EU's declaratory policy has addressed an increasingly large spectrum of international questions, the member states' collective capability of external force projection suffers from serious limitations. Moreover, much continues to be done by the member countries individually and, despite the loyalty and mutual solidarity obligations, it is not rare that their national foreign policy initiatives follow different if not contrasting objectives and strategies. Hence the need to expand the Union's sphere of international action, by which I mean the range of foreign policy issues that the member states address by resorting to the Union's instruments rather than to national ones. The proposed MFA could play a crucial role even in this regard, for one of his/her tasks is to "contribute by his or her proposals to the development of common foreign policy." Based on these constitutional powers, the MFA could give a decisive impulse to the expansion of the Union's CFSP activities, including the member states' collective presence in a growing number of regions of common interest. The draft constitutional treaty envisages, in particular, a wider scope for the security and defense component of the CFSP - the so-called Common European Security and Defense Policy (CESDP) - by entrusting the Union with new tasks, including "supporting third countries in combating terrorism in their territories." This prospective expansion of the areas covered by the CFSP may offer new opportunities for concrete cooperation between the EU and the U.S., particularly in dealing with the new security threats.

\section{Decision-making Procedures}

Few voices within the Convention asked that the communitarian method, which would involve a power of co-decision for the European Parliament, be extend-

\footnotetext{
${ }^{1}$ For full text of the Draft EU Consititution, see the pdf file at website http://www.jcwi.org.uk/lawpolicy/eurolaw/Draft $\% 20$ EU\%20consitution $\% 20 \mathrm{May} \% 2003$.pdf
} 
ed to foreign and security policy. In fact, according to the draft constitutional treaty, decisions on CFSP matters would continue to be made by the heads of state or government within the European Council and by the foreign affairs ministers within the Council of Ministers, on the basis of the intergovernmental method. The European Parliament would continue to have only the right to be consulted and kept regularly informed of the developments of CFSP. However, there was an intense debate within the Convention on the changes to be introduced in the Council's decision-making procedures related to CFSP issues. While many members of the Convention spoke in favor of establishing qualified majority voting (QMV) as a general rule for CFSP-related issues as well, others wanted to maintain unanimity as the method of choice. The draft treaty retains unanimity as the general rule, with a very limited extension of the type of cases which would be subjected to QMV. The latter would continue to apply to decisions concerning the implementation phase of already agreed common positions or actions. Moreover, the Council of Ministers would make by qualified majority vote any decisions: (a) based on a previous deliberation of the European Council concerning the Union's strategic interests and objectives, or; (b) relating to a proposal made by the MFA following a request from the European Council. In practice, a unanimous vote would continue to be required, either in the European Council or the Council of Ministers, at the start of any decision-making processes concerning major CFSP issues. No less important, the draft treaty reaffirms the right of any state to block the use of QMV by appealing to "important and stated reasons of national policy," a provision that has always represented a major obstacle to effective decision-making in the CFSP field. Finally, as under the current treaty, QMV would not apply to decisions having military or defense implications. In sum, the modest improvements contained in the draft treaty provide no guarantees against the risk that differences between the member states may result in new cases of decision-making paralysis. However, the MFA could facilitate the decision-making process by encouraging, as mentioned above, early consultations on ways to deal with emerging international issues so that the required compromises can be made in a timely fashion.

It is also worth noting that the draft treaty allows the European Council to introduce majority voting in policy areas other than those listed in the treaty. Thanks to this so-called passerelle clause, it would be possible to extend majority voting to CFSP issues without passing through the complicated and lengthy procedure regulating the revision of the treaty. However, since the European Council would have to make the decision to extend qualified majority by unanimous vote, it is doubtful that the "passerelle clause" would ever be used to change the decision-making rules of CFSP, since many member states oppose this idea. 


\section{Flexibility Arrangements}

While the draft treaty introduces only limited innovations concerning CFSP decision-making rules, it contains important new provisions expanding the possibilities for limited groups of willing and able states to establish closer forms of cooperation among themselves in the CFSP realm. This can partially mitigate the negative effects of the maintenance of the unanimity rule. In particular, "enhanced cooperation" in the CFSP context would no longer be restricted to the mere implementation of a joint action or a common position as established in the current treaty. Moreover, independent of the provisions regulating "enhanced cooperation," the draft treaty gives the Council the power to entrust "the implementation of a task to a group of Member States having the necessary capability and the desire to undertake the task." This means, among other things, that ad hoc coalitions of various member states could perform security actions on behalf of the Union.

In the CESDP field, the draft treaty envisages other forms of closer cooperation involving a limited group of countries. This includes what the draft treaty calls "structured cooperation," which would involve member states with higher military capabilities that are willing to undertake more binding mutual commitments in the defense area. Moreover, the draft treaty calls for the establishment of a new agency for the development of common military capabilities in which only the willing and able states would take part. Finally, a specific form of closer cooperation is also envisaged for mutual defense. The member states participating in such cooperation would commit themselves to mutual assistance "by all means in their power" in case of an armed attack.

Taken together, these new forms of flexibility could not only partially compensate for the shortcomings of the Union's decision-making procedures but could also help the Union to develop its security role and military capabilities more effectively and rapidly, by preventing the laggard and more Euroskeptical countries from dictating the pace of the progressive framing of CESDP. The greater flexibility that the Union would acquire could facilitate the establishment of a more balanced and solid security partnership with the U.S. On the other hand, the new flexibility clauses also ease the way for the consolidation of "vanguard groups" in the CESDP field, something that could heighten the U.S. fear that a European military alternative to NATO could emerge sooner or later.

\section{Institutional Set-up}

Arguably, the creation of the role of an elected full-time President of the European Council, as envisaged by the draft treaty, could contribute substantially to increasing the continuity and consistency of EU activities as well as provide it with more effective leadership. The current six-month rotating presidency is widely seen as incompatible with the ambition to give the Union's actions 
a long-term strategic foundation. This applies, in particular, to the CFSP field. When holding the rotating presidency, the member states have a clear tendency to direct the Union's foreign policy agenda towards their own national interests and concerns, which is one of the main reasons for its volatility. This inconvenience would hopefully be eliminated if the Presidency of the European Council would be assigned, as proposed by the Convention, to an institutional figure for two-and-a-half years instead of, as is the case today, to a representative of a national government for only six months. The proposed new president would be entrusted, in particular, with the task of ensuring the external representation of the Union at the highest level.

However, as outlined above, the most important new office for the development of CFSP would be that of the proposed minister of foreign affairs. As mentioned before, the MFA would be assigned the overall responsibility for ensuring coordination and consistency between the various aspects of the Union's external action. He/she would receive guidance from the Council on all CFSP matters but, at the same time, as a member of the European Commission, be subjected to the Commission's rules as regards the non-CFSP aspects of external actions.

The MFA would be entrusted with a variety of important tasks. One would be the chairmanship of the Foreign Affairs Council. The MFA would have the power, among other things, to convene extraordinary meetings of the Foreign Affairs Council in cases that require a rapid decision. In general, the chairmanship of the Council is an element that could substantially reinforce the power of initiative of the Minister of Foreign Affairs.

The MFA would also have extensive external representation tasks, including expressing the Union's position in international organizations or at international conferences. This can strengthen the Union's ability to speak with a single voice on the international scene, although the draft treaty does not even mention the possibility of a single EU seat on the United Nations Security Council.

The special representatives of the European Council responsible for dealing with specific CFSP issues or geographical areas would also be placed under the authority of the MFA. This goes along with the general program of streamlining the Council's operational structure (currently, the special representatives are formally not under the authority of the High Representative of CFSP, but report directly to the Council). Moreover the MFA will have an important role in identifying the means to be used for various EU missions. He/she could therefore contribute to a more extensive and systematic resort to pooled or shared assets.

Some have cast doubt on the notion that a single institutional figure can effectively perform all these functions. In fact, the draft treaty proposes the creation of a "European external action service" to help the MFA to fulfill his/her mandate. This would not be an easy task to accomplish, considering that 
the current Union delegations in third countries, which would provide the nucleus of the prospective new EU diplomatic service, have so far been involved in CFSP activities only marginally.

Another important question is if the MFA would be able to forge a functional working relationship with the President of the Commission. In fact, thanks to his/her rather large power of initiative, the MFA may acquire substantial political leverage within the Commission, and it is not completely clear how this can be reconciled with the powers and responsibilities of the President of the Commission (which, incidentally, the draft treaty would increase even further). Some also fear that two separate and competing bureaucracies - one under the President of the Commission, the other under the MFA - could eventually emerge within the EU, jeopardizing its unity of action. More generally, there has been a widespread request that the forthcoming intergovernmental conference work to better clarify the respective roles of the President of the European Council, the MFA, and the President of the Commission with a view toward minimizing the risk of damaging competition or rivalries between them.

\section{Conclusion}

The intergovernmental conference, which will have the final say on the EU's constitutional reform, is expected to make only minor adjustments to the draft treaty approved by the European Convention. However, even if the subsequent ratification process proceeds smoothly, the new treaty is unlikely to take effect before 2006. In the meantime, transatlantic relations will have to face new challenges and, as a result, will probably undergo major transformations. Nevertheless, when enacted, the constitutional reform of the CFSP will not remain without consequences for the EU-U.S. partnership. Some structural deficiencies of the CFSP would remain, notably the veto power of single member states on key decisions. The Union would hence continue to be exposed to the risk of decision-making blockages. Moreover, it is uncertain if the new institutional triangle - President of the European Council-Minister of Foreign Affairs-President of the Commission - will work effectively. On the other hand, the new proposed instruments for external action could contribute significantly to filling the gap between the EU's ambitions and its actual capabilities. This would make the EU a more effective partner for the U.S. The Union can also become, especially through the action of the MFA, more capable of speaking with a single voice on the world scene. No less important, the Union can also acquire a growing capability to develop long-term strategic guidelines for its foreign policy, which would allow for a more meaningful dialogue with the U.S. regarding strategic priorities as well as on the ways and means to deal with them. Seen from a different prospective, a stronger and more cohesive Union would be able not only to exert a greater influence on Washington but also to oppose more effectively the U.S. choices with which it disagrees. The prospec- 
THE QUARTERLY JOURNAL

tive strengthening of CFSP would therefore not only offer new opportunities for transatlantic cooperation but also put to the test its continued vitality. 


\section{Bibliography}

Draft EU Consititution., 2003. 